\title{
PERANCANGAN APLIKASI MOBILE CATALOG MODEL RAMBUT DENGAN MENERAPKAN ALGORITMA CROCHEMORE PERRIN
}

\author{
Sri Hardiyanti
}

\author{
Program Studi Teknik Informatika STMIK Budi Darma, Medan
}

\begin{abstract}
Abstrak
Dijaman modern sekarang, barbershop alias tempat cukur pria menjadi pilihan utama pria modern untuk menata rambutnya. Hasil penelitian menunjukkan bahwa popularitas Barbershop itu sendiri disebabkan adanya tren model rambut yaitu model rambut klasik. Tren model rambut klasik juga didukung oleh media yang berdampak positif pada popularitas, fesyen rambut sebagai prioritas, pengetahuan tentang fesyen menjadi lebih baik, tren pomade. Pada umumnya customer ingin mendapatkan kualitas terbaik dari layanan yang disediakan.Perubahan model potongan rambut customer atau pelanggan Barbershop biasanya disebabkan oleh pergantian tren atau juga karna ingin mencari model baru yang lebih sesuai dengan usia. Katalog model potongan rambut merupakan suatu buku yang berisikan informasi berbagai model potongan rambut yang dibuat dalam bentuk gambar serta nama dari potongan rambut, dimana nama potongan rambut tersebut pada umumnya dibuat dalam bahasa Inggris. Masalah yang dapat terjadi dalam memotong rambut adalah kurang sesuainya keinginan dari customer terhadap hasil potongan hair stylist, hal tersebut terjadi karna customer kurang paham atau kurang ingat dengan nama model potongan rambut yang diinginkan. Algoritma Crochemore Perrin memfaktorkan pattern kanan sehingga pattern=pattern kiri pattern kanan. Fase pencocokan pada algoritma ini terdiri dari dua bagian, pertama mencocokan karakter pattern kanan dari kiri ke kanan, lalu mencocokan pattern kiri dari kanan ke kiri.
\end{abstract}

Kata Kunci : Barbershop, Android, Katalog, Crochemore Perrin

\begin{abstract}
In modern times, barbershop aka men's shaving places is the main choice of modern men to style their hair. The results showed that the popularity of Barbershop itself is due to the trend of the haircut, the classic hairdo. Classic hairstyle trends are also supported by the media which has a positive impact on popularity, hair fashion as a priority, knowledge about fashion is getting better, pomade trends. In general, customers want to get the best quality of services provided.Changes in customer haircuts or Barbershop customers are usually caused by changing trends or because they want to find new models that are more ageappropriate. The haircut catalog is a book that contains information on various haircut models that are made in the form of pictures and names of haircuts, where the names of haircuts are generally made in English.The problem that can occur in cutting hair is the lack of desires of the customer to the results of the hair stylist cut, it happens because the customer does not understand or do not remember the name of the desired haircut model. Crochemore Perrin's algorithm factored the right pattern so that pattern = right pattern left pattern. The matching phase of this algorithm consists of two parts, first matching the right pattern character from left to right, then matching the left pattern from right to left.
\end{abstract}

Keywords: Barbershop, Android, Catalog, Crochemore Perrin

\section{PENDAhuluan}

Manusia memiliki berbagai macam anggota tubuh yang selalu diperhatikan. Setiap anggota tubuh mempunyai fungsi dan arti penting yang berkaitan dengan aktivitas sehari-hari. Setiap manusia mempunyai prioritas tersendiri dalam menentukan kadar perhatian yang biasa dituangkan terhadap salah satu anggota tubuh tersebut. Salah satu anggota tubuh yang sering menjadi perhatian adalah rambut karena rambut merupakan salah satu penunjang penampilan baik itu perempuan maupun laki-laki.

Pada tahun 1990 sampai dengan tahun 1998 masyarakat mengenal tempat cukur sebagai tempat memotong atau merapikan rambut laki-laki, kini barbershop alias tempat cukur pria menjadi pilihan utama pria modern untuk menata rambutnya. Bila sebelumnya para tukang cukur hanya bermodalkan cermin, gunting, dan sisir, kini di barbershop para pelanggan bisa mendapat layanan yang nyaman dan model rambut yang lebih kekinian. Hasil penelitian menunjukan bahwa popularitas barbershop disebabkan adanya tren model rambut yaitu tren rambut klasik. Tren model rambut klasik juga didukung oleh media. Dampak positif popularitas : fesyen rambut sebagai prioritas, pengetahuan tentang fesyen menjadi lebih baik, tren pomade. Dampak negatifnya : perilaku konsumtif dan tergusurnya pasar pangkas rambut. Dalam barbershop ada terdapat beberapa istilah yang sering digunakan seperti : Clippers yang berarti gunting, Thinning Scissor yang artinya gunting peni pisan, Razor yang berarti pisau cukur, Comb yang berarti sisir, Waterboard yang berarti tempat mencuci rambut, Turban yang berarti serban, dan Barberman (Hair Stylist) sebutan untuk profesi seorang penata rambut profesional[1].

Client atau pelanggan merupakan pengguna jasa dari suatu fasilitas atau layanan, pada umumnya client ingin mendapatkan kualitas terbaik dari layanan yang disediakan. Perubahan model potongan rambut client atau pelanggan barbershop biasanya disebabkan oleh pergantian trend atau juga karena ingin mencari model baru. Beberapa model potongan rambut memang memiliki sebutan dari model potongan rambut tersebut seperti belah tengah, belah samping, atau jambul. Tetapi beberapa jenis model potongan rambut lain menggunakan sebutan yang cukup aneh atau unik didengar seperti pompadour, undercut, dan masih banyak lagi yang lainnya. Untuk itu diperlukan suatu aplikasi katalog model rambut agar pelanggan dapat memilih model rambut yang diinginkan. 
Katalog model potongan rambut merupakan suatu buku yang berisikan informasi berbagai model potongan rambut yang dibuat dalam bentuk gambar serta nama dari potongan rambut, dimana nama potongan rambut tersebut pada umumnya dibuat dalam bahasa Inggris. Masalah yang dapat terjadi dalam memotong rambut adalah kurang sesuainya keinginan dari customer terhadap hasil potongan hair stylist, Hal tersebut terjadi karena client kurang paham atau kurang ingat dengan nama model potongan rambut yang diinginkan. Selain dari masalah tersebut client juga kurang tahu model yang diinginkan karena katalog tersebut hanya tersedia di barbershop.

Algoritma pencarian string atau sering disebut juga algoritma pencocokan string yaitu algoritma untuk melakukan pencarian semua kemunculan string pendek dan panjang, untuk string pendek yang disebut pattern dan string yang lebih panjang yang disebut teks.

Algoritma Crochemore Perrin yang sering juga disebut algoritma dua arah (Two Way Algorithm) dipublikasikan Maxime crochemore dan Dominique Perrin pada tahun 1991. Algoritma Crochemore Perrin memfaktorkan pattern kanan sehingga pattern=pattern kiri pattern kanan. Fase pencocokan pada algoritma ini terdiri dari dua bagian, pertama mencocokkan karakter pattern kanan dari kiri ke kanan, lalu mencocokkan pattern kiri dari kanan ke kiri[2].

Menurut penulis algoritma Crochemore Perrin dapat diterapkan sebagai pencarian nama model potongan rambut berdasarkan penelitian sebelumnya yang dilakukan oleh Boby Halim Lukmana, "Penerapan Algoritma Crochemore Perrin Pada Pencarian Jurnal Berbasis Mobile" menyimpulkan bahwa penerapan algoritma Crochemore Perrin dapat bekerja di dalam aplikasi mobile jurnal. Aplikasi Mobile Jurnal mampu memberikan kemudahan kepada pengguna smartphone android dalam melakukan pencarian jurnal. Dimana kemudahan yang diberikan berupa mencari judul jurnal yang memiliki kesamaan atau kemiripan dengan kata yang telah disimpan sebelumnya didalam database[2].

\section{TEORITIS}

\subsection{String Matching}

String matching adalah proses pencarian semua kemunculan query yang selanjutnya di sebut Pattern kedalam string yang lebih pajang (text). Pattern di lambangkan dengan $\mathrm{x}=\mathrm{x}[0 \ldots \mathrm{m}-1]$ dan panjangnya adalah $\mathrm{m}$. Text di lambangkan dengan $\mathrm{y}=\mathrm{y}[0 \ldots . \mathrm{n}-1]$ dan panjangnya adalah $\mathrm{n}$. kedua string terdiri dari sekumpulan karakter yang disebut alphabet yang di lambangkan dengan $\sum$ dan mempunyai ukuran $\sigma$. Algoritma string matching mempunyai tiga komponen yaitu:

1. Pattern, yaitu deretan karakter yang di cocokan dengan text

2. Text, yaitu tempat pencocockan pattern di lakukan

3. Alfabet, yang berisi semua simbol yang di gunakan oleh bahasa pada text pattern

String merupakan bagian penting dari sebuah proses pencarian string (string searching) dalam sebuah dokumen. Hasil dari pencarian sebuah string dalam dokumen tergantung dari teknik atau cara pencocokan string yang di gunakan[3].

\subsection{Algoritma Crochemore Perrin}

Algoritma Crochemore-Perrin, yang sering juga disebut algoritma Two Way Algorithm, atau Algoritma Dua Arah dipublikasikan Maxime Crochemore dan Dominique Perrin pada tahun 1991. Algoritma ini memfaktorkan pattern menjadi dua bagian pattern kiri, dan pattern kanan sehingga pattern=pattern kiri pattern kanan. Fase pencocokan pada algoritma ini terdiri dari dua bagian, pertama mencocokkan karakter pattern kanan dari kiri ke kanan, lalu mencocokkan karakter patternkiri dari kanan ke kiri.

Fase inisialisasi pada algoritma ini menghitung faktorisasi yang baik dari pattern atas pattern kiri dan pattern kanan. Jika (u, v) merupakan sebuah faktorisasi dari pattern, maka sebuah pengulangan di (u, v) adalah sebuah kata w, sehingga dua persyaratan ini terpenuhi:

1. w adalah akhiran dari $\mathrm{u}$ atau $\mathrm{u}$ adalah akhiran dari $\mathrm{u}$

2. $\mathrm{w}$ adalah awalan dari $\mathrm{v}$ atau $\mathrm{v}$ adalah awalan dari $\mathrm{w}$

Algoritma Crochemore-Perrin memilih faktorisasi kritis (pattern kiri, attern kanan) sehingga |pattern kiri| < per (x) dan |pattern kiri| mempunyai nilai minimal. Dengan kata lain, kata w muncul di kedua sisi dari potongan u dan $\mathrm{v}$ dengan kemungkinan over flow di kedua sisi. Panjang dari pengulangan terkecil di (u, v) disebut periode lokal, dan dinotasikan dengan $r(u, v)$. Setiap faktorisasi dari (u, v) paling tidak mempunyai satu pengulangan. Dapat dilihat dengan mudah bahwa $1 \mathrm{r}(\mathrm{u}, \mathrm{v})|\mathrm{x}|$. Faktorisasi $(\mathrm{u}, \mathrm{v})$ dari $\mathrm{x}$ sehingga $\mathrm{r}(\mathrm{u}, \mathrm{v})=\operatorname{per}(\mathrm{x})$ disebut faktorisasi kritis dari $\mathrm{x}$. Jika $(\mathrm{u}, \mathrm{v})$ adalah faktorisasi kritis dari $\mathrm{x}$, maka pada posisi pada $|\mathrm{u}|$ di $\mathrm{x}$, periode lokal dan periode global akan sama[2].

\subsection{Analisa}

Katalog model potongan rambut pada umumnya berisikan informasi berbagai model potongan rambut yang dibuat dalam bentuk gambar serta nama dari potongan rambut, dimana nama potongan rambut tersebut dibuat dalam 
bahasa Inggris. Masalah yang dapat terjadi dalam memotong rambut adalah kurang sesuainya keinginan dari customer terhadap hasil potongan hair stylist karena client kurang paham atau kurang ingat dengan nama model potongan rambut yang diinginkan.

Dari permasalahan tersebut maka penulis membangun suatu aplikasi kumpulan model potongan rambut berbasis android. Penulis membangun aplikasi tersebut dengan menerapkan algoritma crochemore perrin dengan tujuan untuk memudahkan pengguna aplikasi mendapatkan model potongan rambut yang diinginkan.

Untuk melakukan pencarian model potongan rambut pada aplikasi kompulan model potongan rambut, user memasukkan potongan nama dari model potongan rambut, yang kemudian dilakukanlah proses pencarian menurut algoritma crochemore perrin, dari potongan nama model potongan rambut tersebut dijadikan sebagai pattern dan teks merupakan nama model potongan rambut dari SQLite. Proses pencocokan atau pencarian akan dilakukan secara berulang-ulang sebanyak jumlah record pada SQLite, hasil dari perbandingan tersebut akan ditampilkan dalam bentuk daftar pencarian.

\subsection{Penerapan}

Penulis dalam melakukan penerapan algoritma Crochemore Perrin pada pencarian model potongan rambut terlebih dahulu menentukan teks yang akan digunakan sebagai acuan pencarian, dalam penelitian tersebut penulis menentukan teks adalah "THE FRENCH COP" dan dengan asumsi pattern adalah "FRENCH". Setelah teks dan pattern ditentukan maka tahap selanjutnya adalah melakukan proses pencarian berdasarkan Crochemore Perrin, dapat dilihat pada gambar dibawah ini.

Teks : THE FRENCH COP

Pattern : FRENCH

Tabel 1. Processing Tahap Pertama

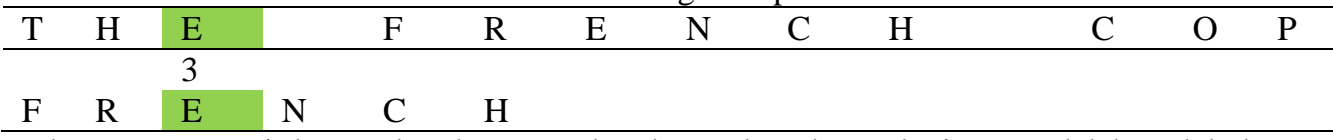

Karakter E pada pattern sesuai dengan karakter E pada teks, maka tahap selanjutnya adalah melakukan perbandingan satu karakter selanjutnya.

Tabel 2. Processing Tahap Kedua

\begin{tabular}{|c|c|c|c|c|c|c|c|c|c|c|c|}
\hline $\mathrm{T}$ & $\mathrm{E}$ & & $\mathrm{F}$ & $\mathrm{R}$ & $\mathrm{E}$ & $\mathrm{N}$ & $\mathrm{C}$ & $\mathrm{H}$ & $\mathrm{C}$ & $\mathrm{O}$ & $\mathrm{P}$ \\
\hline & & 1 & & & & & & & & & \\
\hline 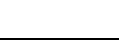 & & $\mathrm{F}$ & $\mathrm{R}$ & $\mathrm{E}$ & $\mathrm{N}$ & $\mathrm{C}$ & $\mathrm{H}$ & & & & \\
\hline
\end{tabular}

Karakter $\mathrm{F}$ pada pattern tidak sesuai dengan karakter spasi pada teks, sehingga persegesaran selanjutnya adalah 1.

Tabel 3. Processing Tahap Ketiga

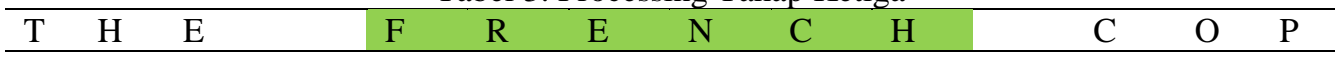

F $\quad$ R $\quad$ E $\quad \mathrm{N} \quad \mathrm{C} \quad \mathrm{H}$

Pattern ditemukan, karena setiap pattern dan teks sesuai.

Adapun perancangan antar muka merupakan sebuah gambaran atau perencanaan serta pembuatan sketsa atau pengaturan dari beberapa elemen yang terpisah menjadi satu kesatuan yang utuh dan berguna bagi banyak orang. Berikut ini adalah perancangan antarmuka pada aplikasi kumpulan model potongan rambut.

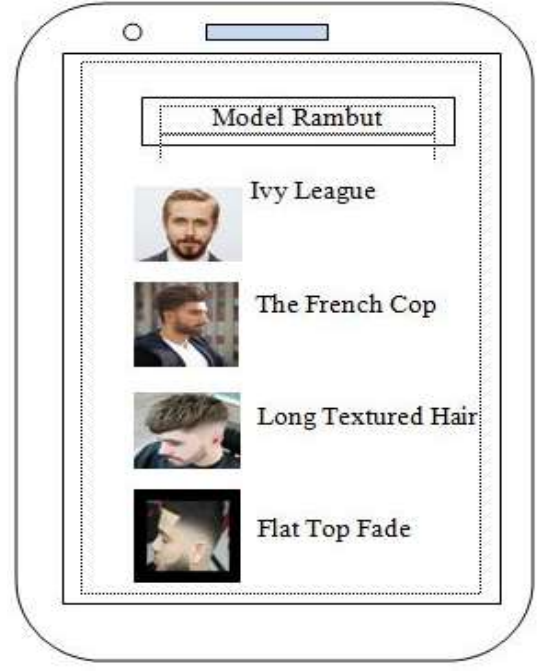

Gambar 1. Rancangan Aplikasi 


\section{KESIMPULAN}

Berdasarkan dari penelitian yang telah dilakukan, maka hasil akhir dari penelitian tersebut dapat diambil beberapa kesimpulan dari pembahasan sebelumnya. Adapun kesimpulan tersebut sebagai berikut:

1. Prosedur pada aplikasi mobile katalog model rambut dalam mengirim sebuah file Penerapan algortima Crochemore Perrin.

2. Penerapan algoritma Crochemore Perrin untuk aplikasi katalog model rambut sangat efektif

3. Perancangan aplikasi katalog model rambut menggunakan Eclipse Juno.

\section{REFERENCES}

[1] R. Rahim, "Keylogger Application to Monitoring Users Activity with Exact String Matching Algorithm Keylogger Application to Monitoring Users Activity with Exact String Matching Algorithm," 2018.

[2] D. Tetap, S. Budi, and D. Medan, "IMPLEMENTASI ALGORITMA STRING MATCHING DALAM PENCARIAN SURAT DAN AYAT DALAM BIBLE BERBASIS ANDROID Efori Buulolo Diterbitkan Oleh: STMIK Budi Darma Medan Diterbitkan Oleh : STMIK Budi Darma Medan,” vol. III, pp. 23-27, 2013.

[3] N. Marbun, M. Zarlis, D. Hartama, and B. J. D. Sitompul, "Implementasi Algoritma Raita Pada Pencarian Katalog Alkes," pp. 520-523, 2019. 